\title{
Studies on Ionic Interactions between a Glycosaminoglycan Chondroitin-6-sulfate and Lysine-Containing Polypeptides by NMR Spectroscopy
}

\author{
Kwan-Jun Jeon, Kaname Katsuraya, Yutaro Kaneko,* \\ Toru Mimura, ${ }^{*}$ and Toshiyuki URYU ${ }^{\dagger}$ \\ Institute of Industrial Science, The University of Tokyo, 7-22-1 Roppongi, Minato-ku, Tokyo 106, Japan \\ * Ajinomoto Co., Kyobashi, Chuo-ku, Tokyo 104, Japan
}

(Received June 24, 1997)

\begin{abstract}
The interactions between chondroitin-6-sulfate (COS) and lysine derivatives such as oligolysines, polylysines (PL), and copolylysines were examined to elucidate functions of bioactive sulfated glycosaminoglycans by means of NMR spectroscopy. Gellike complexes were obtained by the ionic interactions of sulfate and carboxyl anions of COS with ammonium cations of lysine derivatives having molecular weights more than $771 \mathrm{Da}$. NMR spectra revealed that the gellike complex was formed by the reaction between the two starting materials. The proportion of the gellike complex changed with $\mathrm{pH}$, molar ratio, concentration, and molecular weight of polylysine. Maximum amount of the gellike complex was attained in a combination of $\mathrm{COS}$ with polylysine or hydrophilic copolylysine in the ionic ratio of 1.0. Molecular motions of saccharide and polylysine backbone in the gellike complex were affected by the degree of cross-linking and the extent of ionic interactions.

KEY WORDS Sulfated Glycosaminoglycan / Chondroitin Sulfate / Polylysine / Ionic Interaction / Polyion

Complex /
\end{abstract}

Proteoglycans of chondroitin sulfate, dermatan sulfate, heparan sulfate, and keratan sulfate are important constituents of intracellular granules and extracellular matrices. ${ }^{1,2}$ Proteoglycans are involved in various biological functions such as cell adhesion, cell-tocell communication, and modulation of growth factor activities. ${ }^{3,4}$

In particular, chondroitin sulfates included in chondroitin sulfate proteoglycans (CSPG) are composed of an alternative repeating sequence of D-glucuronic acid and $\mathrm{N}$-acetyl-D-galactosamine with sulfate groups either at the $\mathrm{C} 6$ or $\mathrm{C} 4$ position. ${ }^{5}$ It acts as an adhesion inhibitor and a promoter of migration of cells. ${ }^{6}$ Recently, it was revealed that CSPG controls neurite extension by forming impenetrable barriers against growing axons and prevent neuronal processes from inhibiting of growing of neurite in brain. ${ }^{7,8}$ It was also reported that appicans, that is, cell-associated chondroitin sulfate proteoglycans, contain Alzheimer amyloid precursor protein (APP) as a core protein..$^{9,10}$

It is assumed that biological activities of proteoglycans are mainly caused by specific interactions between sulfated glycosaminoglycans and proteins. ${ }^{11-13}$ However, action mechanisms of these biological functions were not fully understood.

In the previous papers, ionic interactions between negatively-charged sulfated polysaccharides and positively-charged polylysine were analyzed in order to clarify the action mechanism of the biologically active sulfated polysaccharides such as anti-HIV (human immunodeficiency virus) and anticoagulant activities by NMR spectroscopy. ${ }^{14,15}$

In this paper, this NMR methodology is applied to systems of chondroitin-6-sulfate (COS) with polylysine and several copolylysines containing hydrophilic or hydrophobic amino acids to elucidate biological mechanisms of the sulfated glycosaminoglycan as an ex-

\footnotetext{
${ }^{\dagger}$ To whom correspondence should be addressed
}

tracellular component. This paper reports formation of ionic complexes from the two polymers as a function of molar ratio, $\mathrm{pH}$, concentration, and molecular weight of polylysines by using NMR spectroscopy. Interaction behaviors of COS are compared with other sulfated polysaccharides such as curdlan sulfate and heparin.

\section{EXPERIMENTAL}

\section{Materials}

COS sodium salt with $\bar{M}_{w}$ of $60 \times 10^{3}$ was purchased from Sigma. Curdlan sulfate sodium salt contains $14.4 \%$ of sulfur with a weight average molecular weight of $79 \times 10^{3}$ was kindly provided from Ajinomoto Co. Heparin sodium salt with $\bar{M}_{w}$ of $3 \times 10^{3}$ isolated from bovine intestinal mucosa was purchased from Sigma. Lysine hydrochloride was obtained from Junsei Chemical Co., Tokyo. Lysine dimer hydrochloride, oligolysine acetates from trimer to pentamer, poly(L-lysine) hydrobromide $\left(\bar{M}_{w} 2.7 \times 10^{3}-346.5 \times 10^{3}\right)$, and copolylysines composing lysine-alanine $(1: 1$ and $3: 1)$, lysine-phenylalanine (1:1), lysine-serine (3:1), lysine-tryptophan (4:1), and lysine-tyrosine $(4: 1)$ with $\bar{M}_{w}$ of $50 \times 10^{3}$, $31 \times 10^{3}, 33 \times 10^{3}, 32 \times 10^{3}, \quad 38 \times 10^{3}$, and $25 \times 10^{3}$, respectively, were purchased from Sigma. All materials were used without further purification.

\section{Preparations of Polyion Complexes}

Samples for the NMR measurements were prepared as follows. A COS solution in different concentrations was added to an aliquot of $2.8 \%(\mathrm{w} / \mathrm{v})$ solutions of lysine derivatives in NMR tube, followed by shaking for 2 min. The solution was kept at $37^{\circ} \mathrm{C}$ for $1 \mathrm{~h}$, unless otherwise mentioned. In the cases of measurement of the amount of gellike complexes, $1.0 \%(\mathrm{w} / \mathrm{v})$ of polylysine or copolylysine solutions were used. The $\mathrm{pD}$ of the samples was adjusted using $\mathrm{NaOD}$ or $\mathrm{DCl}$. pD was measured with a TOA HM-30V pH meter with GS-5016 electrode by reading the $\mathrm{pH}$ of solutions in $\mathrm{D}_{2} \mathrm{O}$ with- 
out correction.

\section{Measurement}

$400 \mathrm{MHz}{ }^{1} \mathrm{H}$ and $100 \mathrm{MHz}{ }^{13} \mathrm{C}$ NMR spectra were recorded on a JEOL Lambda-400 spectrometer. 4,4Dimethyl-4-silapentane-1-sulfonate (DSS) and methanol solutions were used as the internal standard for ${ }^{1} \mathrm{H}$ and ${ }^{13} \mathrm{C}$ NMR measurements, respectively. Tetramethylsilane (TMS) was used as reference zero.

\section{RESULTS AND DISCUSSION}

\section{NMR Spectra of Mixtures of COS with Polylysine}

When COS was mixed with a lysine derivative in an aqueous solution, polyion mixtures were obtained in the form of clear solution, gellike material, and precipitate. Formation of aggregates mainly depended on the molecular weight of lysine derivatives. Clear solution was obtained by mixing COS with low molecular weight oligolysines smaller than a trimer, while precipitates were formed with polylysines larger than molecular weight of $56 \times 10^{3}$. On the other hand, gellike materials were observed on the wall of NMR tube from turbid mixture solutions of COS with lysine derivatives of tetramer to polylysines with the molecular weight of a few ten thousands.

To elucidate in detail these phenomena and molecular state of gellike materials, ionic interactions between the two kinds of polymers were examined by NMR spectroscopy.

${ }^{1} \mathrm{H}$ NMR spectra of mixtures consisting of COS with $\bar{M}_{w}$ of $60 \times 10^{3}$ and polylysine hydrobromide $(\mathrm{PL} \cdot \mathrm{HBr})$ with $\bar{M}_{w}$ of $7.5 \times 10^{3}$ in different molar ratios were measured. As shown in Figure 1, ${ }^{1} \mathrm{H}$ NMR spectra varied to a large extent by the molar ratio of COS to PL. New absorptions of polylysine side chains assignable to the gellike material formed by mixing $\mathrm{COS}$ with $\mathrm{PL} \cdot \mathrm{HBr}$ appeared approximately $0.15 \mathrm{ppm}$ upfield from the corresponding proton peaks of the polylysine hydrobromide. In particular, absorptions of the $\varepsilon$ proton of polylysine due to gellike material $\left(\varepsilon_{\mathrm{g}}\right)$ and polylysine hydrobromide $\left(\varepsilon_{\mathrm{HBr}}\right)$ appeared separately at 2.90 and $3.04 \mathrm{ppm}$, respectively. Therefore, it was revealed that the gellike material is a polymeric complex formed by interactions between negatively charged COS and positively charged polylysine.
Chemical shifts of the individual absorptions are demonstrated in Table I. The $\varepsilon_{\mathrm{g}}$ absorption almost exclusively appeared at $2.90 \mathrm{ppm}$ in the molar ratio of 1.0. Above the molar ratio 1.0, the chemical shift of $\varepsilon_{\mathrm{g}}$ shifted downfield with increasing molar ratio, reaching to $2.95 \mathrm{ppm}$ in the molar ratio of 3.0 . The gellike material finally disappeared in the molar ratio of 5.0.

Intensity ratios of the gellike complex to the free $\mathrm{PL} \cdot \mathrm{HBr}$ depended on the molar ratio. In the range of

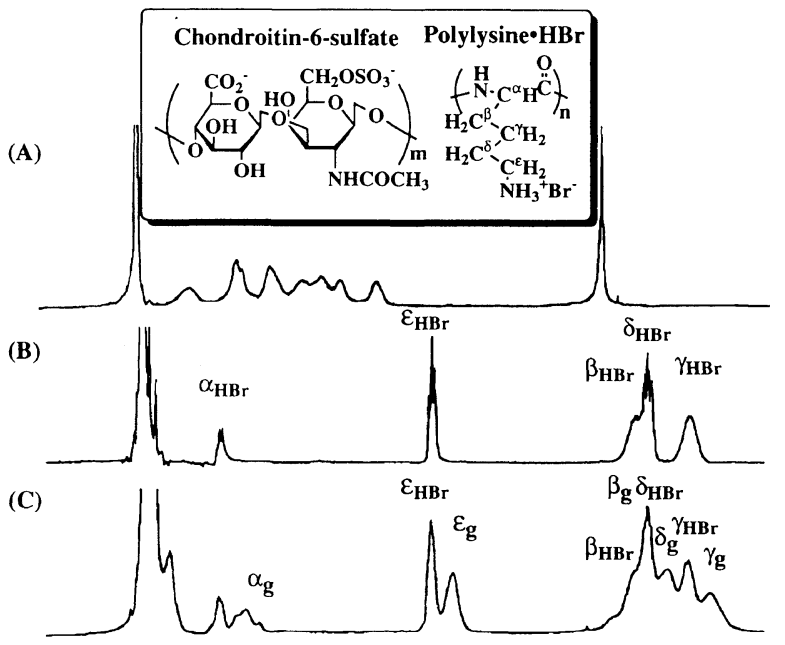

(D)
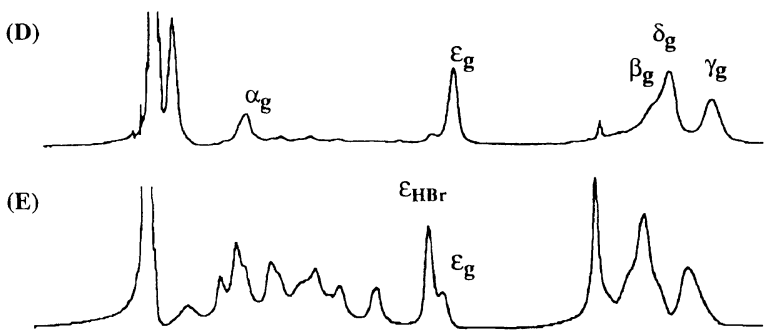

(F)

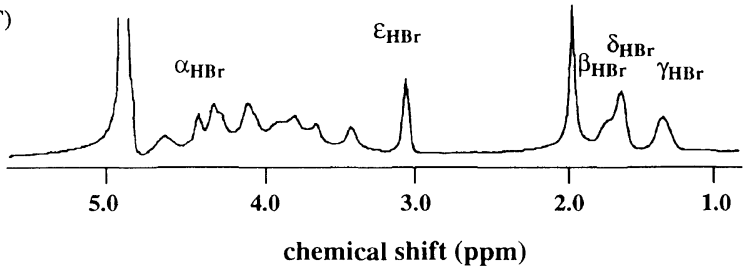

Figure 1. $400 \mathrm{MHz}{ }^{1} \mathrm{H}$ NMR Spectra of polyion complexes between chondroitin-6-sulfate (COS) and polylysine $\cdot \mathrm{HBr}(\mathrm{PL} \cdot \mathrm{HBr})$ in different molar ratios $[\mathrm{COS} / \mathrm{PL} \cdot \mathrm{HBr}] .(\mathrm{A})$ : $\mathrm{COS},(\mathrm{B}): \mathrm{PL} \cdot \mathrm{HBr}$, and mixtures in the molar ratio of $(\mathrm{C}): 0.5$, (D): $1.0,(\mathrm{E}): 3.0$, and $(\mathrm{F}): 5.0$. The concentration of PL is $2.8 \%(\mathrm{w} / \mathrm{v})$.

Table I. Chemical shifts of polylysine side chains of polylysine $\cdot \mathrm{HBr}$ and polyion complex

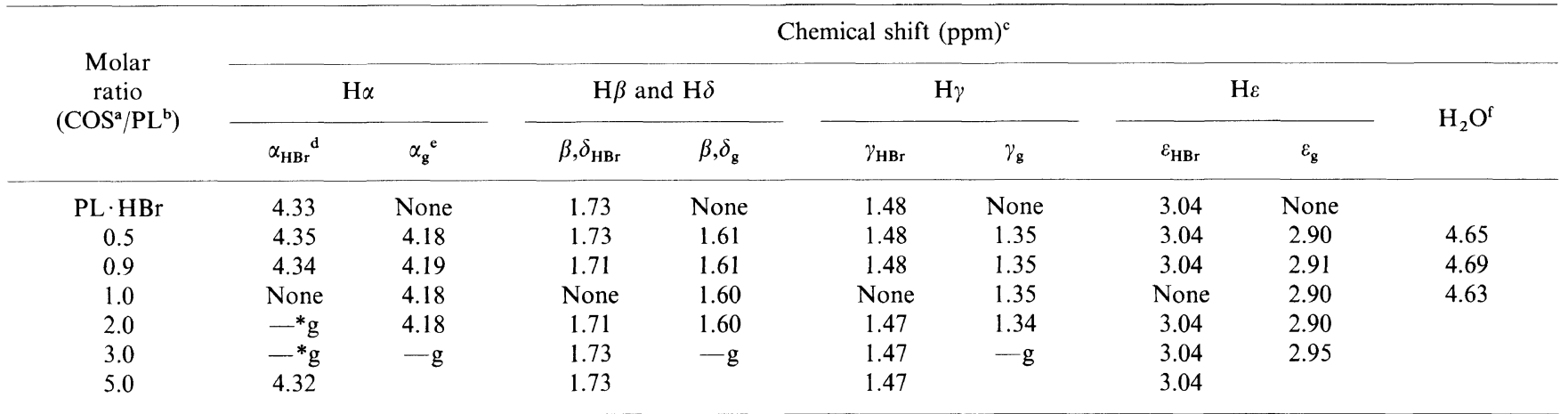

${ }^{\text {a }}$ Chondroitin-6-sulfate with $\bar{M}_{w}$ of $60 \times 10^{3}$. ${ }^{\mathrm{b}}$ Polylysine hydrobromide with $\bar{M}_{w}$ of $7.5 \times 10^{3}$. ${ }^{\mathrm{c}}$ Recorded in D $\mathrm{O}$, using DSS as a standard $(0.015 \mathrm{ppm}) .{ }^{\mathrm{d}}$ Protons of polylysine hydrobromide. ${ }^{\mathrm{e}}$ Protons of polylysine in the gellike complex. ${ }^{\mathrm{f}}$ Entrapped water in the gellike complex. ${ }^{g}$ Overlapped with other peaks. 


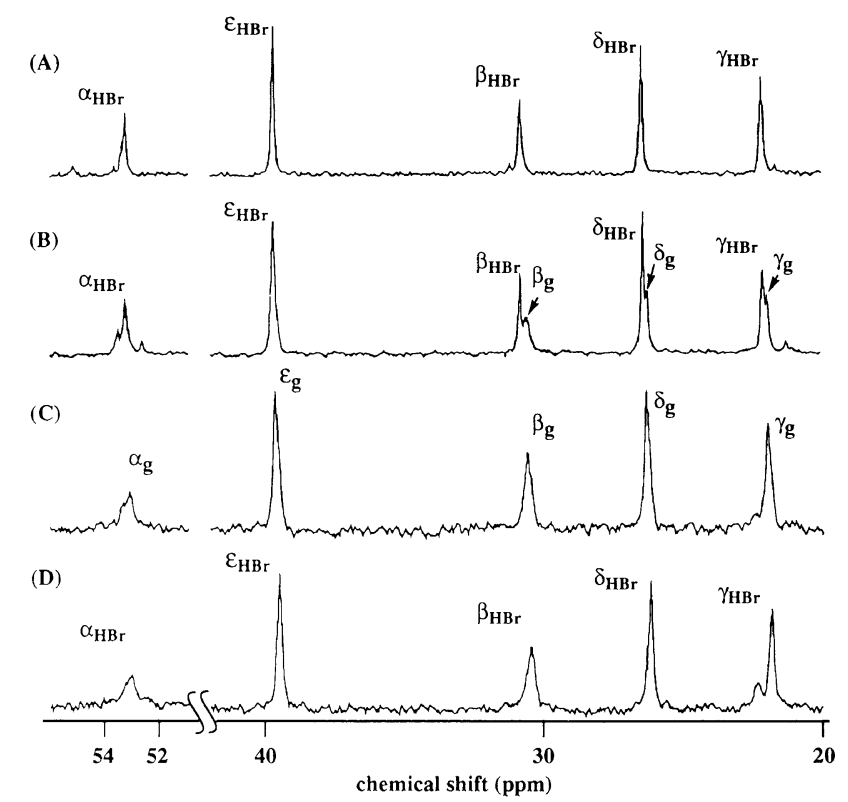

Figure 2. $100 \mathrm{MHz}{ }^{13} \mathrm{C}$ NMR Spectra of polylysine $\cdot \mathrm{HBr}(\mathrm{PL} \cdot \mathrm{HBr})$ and mixtures of $\mathrm{COS}$ with $\mathrm{PL} \cdot \mathrm{HBr}$ in different molar ratios $[\mathrm{COS}] /[\mathrm{PL} \cdot \mathrm{HBr}]$ in the polylysine $\mathrm{C} \alpha$ to $\mathrm{C} \varepsilon$ region. (A): $\mathrm{PL} \cdot \mathrm{HBr}$ and in the molar ratio of (B): 0.5, (C): 1.0, and (D): 5.0.

molar ratios up to 1.0 , the intensity ratio exhibited a tendency to increase with the molar ratio. The maximum proportion of the gellike material of $91 \%$ was attained in the molar ratio of 1.0 .

Figure 2 shows the change in ${ }^{13} \mathrm{C}$ NMR spectrum feature of polylysine side chains by the formation of gellike complex. In the molar ratio of 0.5 , absorptions due to $\beta, \gamma$, and $\delta$ carbons of polylysine side chains were individually split into two peaks due to coexistence of the gellike complex and the unreacted polylysine hydrobromide. In addition, all absorptions shifted upfield by 0.14 to $0.32 \mathrm{ppm}$, compared with those of corresponding $\mathrm{PL} \cdot \mathrm{HBr}$ signals. In the molar ratio of 1.0 , absorptions due to the gellike complex appeared exclusively.

${ }^{13} \mathrm{C}$ NMR absorptions due to the saccharide portion of COS were changed to a large extent with formation of the gellike complex, as shown in Figure 3. In the range of molar ratio of COS to PL increased to 1.0, absorptions due to COS in the gellike complex disappeared as broad baseline, which was also seen in the ${ }^{1} \mathrm{H}$ NMR spectra. Therefore, it was suggested that lowered local motions of the polysaccharide included in the gellike complex prevented the carbon signal from appearing as NMR peaks. Similar phenomena were also observed for curdlan sulfate-polylysine and heparin-polylysine mixtures. ${ }^{14,15}$

Taking into account the result on the NMR measurement, it is supposed that macromolecular ionic interactions between segments of ammonium groups of PL and segments of anion groups of sulfated polysaccharides served not only as neutralization of the polar groups but also as intermolecular cross-linking for formation of the gellike material. Furthermore, it is assumed that a certain proportion of free functional groups which did not participate in the interaction possibly due to their steric circumstances contributed to afford swellability to the polyion complex to form the gellike material.

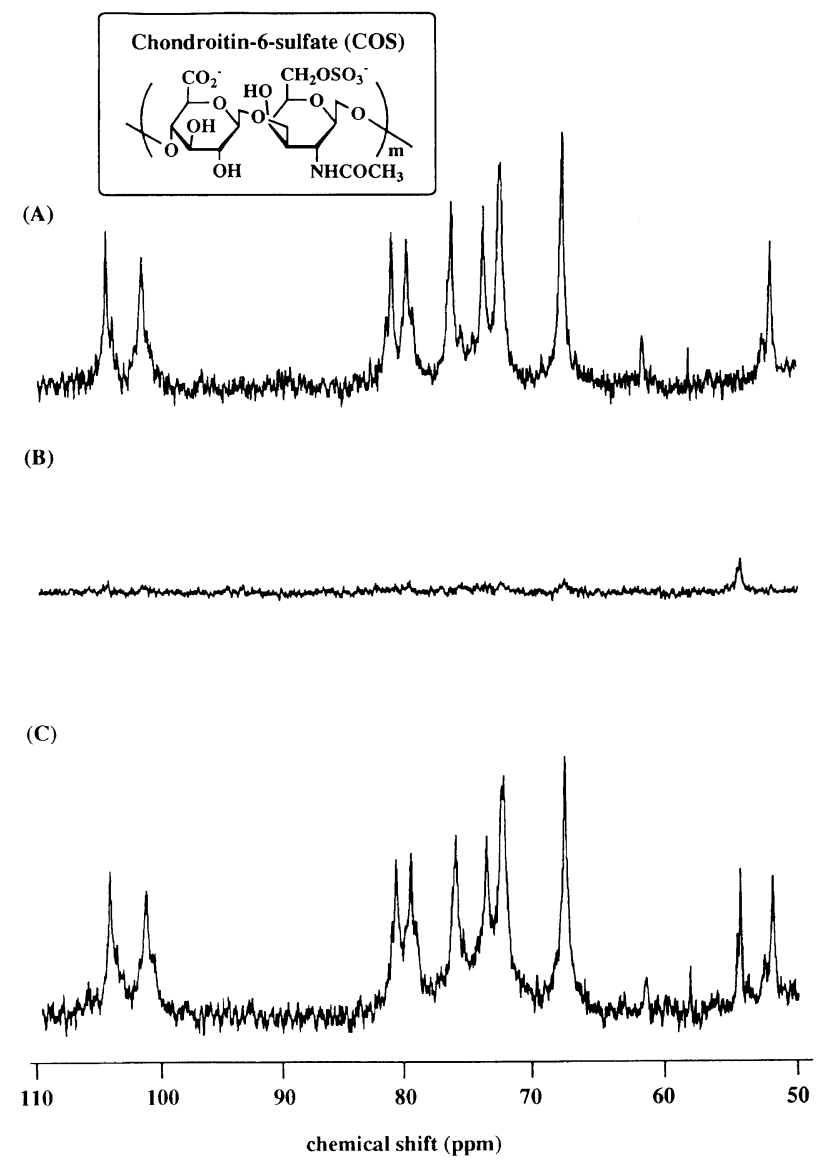

Figure 3. $100 \mathrm{MHz}{ }^{13} \mathrm{C}$ NMR Spectra of $\mathrm{COS}$ and mixtures of COS with $\mathrm{PL} \cdot \mathrm{HBr}$ in different molar ratios $[\mathrm{COS}] /[\mathrm{PL} \cdot \mathrm{HBr}]$ in the COS region. (A): $\operatorname{COS}$ and in the molar ratio of (B): 1.0, and (C): 5.0 .

\section{Molecular State of Gellike Complexes}

It has been reported that the maximum amount of gellike complexes were formed in definite molar ratios depending on the amount of anions in the saccharide unit. ${ }^{14,15}$ The molar ratio giving the maximum amount of gellike complex decreased with increasing amount of anions in sulfated polysaccharides. In fact, in the cases of COS, curdlan sulfate, and heparin having 1.0, 1.5, and 2.0 anions in the saccharide unit, maximum amounts of the gellike complexes were obtained in the molar ratio of the polysaccharide to polylysine of $1.0,0.8$, and 0.6 , respectively.

${ }^{13} \mathrm{C}$ NMR spectra provided useful information about molecular state of gellike complexes. As shown in Figure 4 , broadening of $\alpha$ and $\beta$ absorptions of polylysine in the gellike complex was remarkably influenced by the degree of cross-linking. For heparin system, $\alpha$ and $\beta$ absorptions of polylysine side chains included in the gellike complex disappeared, while, for COS system, the broadening of $\alpha$ and $\beta$ peaks was negligible. The broadening in NMR signals suggested that local motions of the polylysine backbone were more restricted in the heparin system than in the COS.

Chemical shifts of protons for polylysine side chains seem to be also affected by aggregating states of gellike complexes. As shown in Table II, absorptions of gellike complexes formed with COS, curdlan sulfate, and heparin systems, appeared $0.14,0.18$, and $0.23 \mathrm{ppm}$ upfield from the proton peaks of the polylysine $\cdot \mathrm{HBr}$, 
respectively. Taking into account the chemical shift of the $\varepsilon$ protons, it was revealed that the polylysine included in COS system was surrounded by negatively charged polysaccharides in less extent than that in curdlan sulfate and heparin systems, having more local motions as well.

\section{NMR Spectra of Mixtures of COS with Copolylysines}

In biological system, it has been demonstrated that interactions between heparin or heparan sulfate with a neural cell adhesion molecule (NCAM) are based on

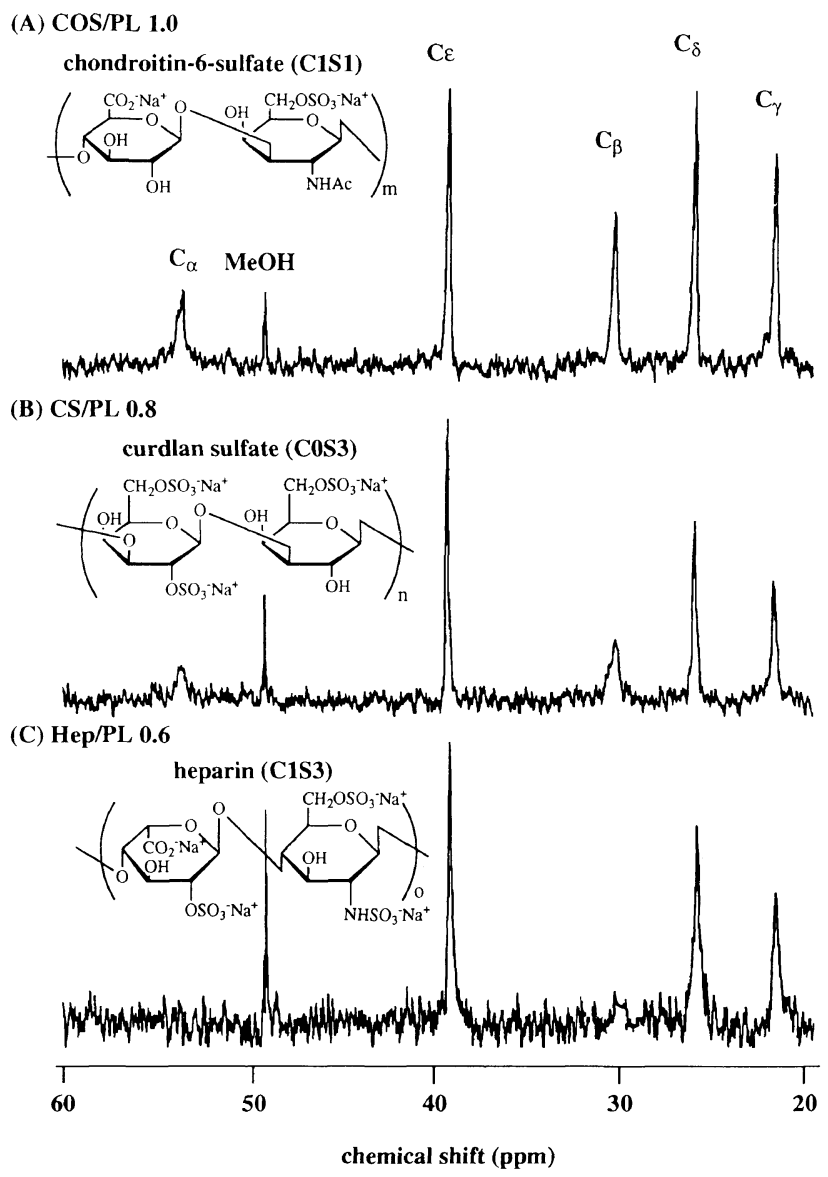

Figure 4. $100 \mathrm{MHz}{ }^{13} \mathrm{C}$ NMR Spectra of gellike polyion complexes by interactions between $\mathrm{PL} \cdot \mathrm{HBr}$ and $\mathrm{COS}$, CS, or Hep at the molar ratio of maximal gellike complex formation in the polylysine $\mathrm{C} \alpha$ to $\mathrm{C} \varepsilon$ region. (A): gellike complex formed in molar ratio of $[\mathrm{COS}] /[\mathrm{PL} \cdot \mathrm{HBr}]$ 1.0, (B): $[\mathrm{CS}] /[\mathrm{PL} \cdot \mathrm{HBr}] 0.8$, and $(\mathrm{C}):[\mathrm{Hep}] /[\mathrm{PL} \cdot \mathrm{HBr}] 0.6$ ionic interactions between the glycosaminoglycan and basic amino acids sequence of the proteins. ${ }^{16}$ Furthermore, it was reported that the adhesiveness of NCAM originates from interactions between the heparan sulfate and the second immunogloblin domain containing six basic amino acids of NCAM. ${ }^{17}$

To construct a model system resembling to real biological systems, interactions of COS with copolylysines were examined. Similarly to the case of COS and PL. $\mathrm{HBr}$ mixture, gellike complexes attached on the wall of NMR tube by mixing COS with copolylysines containing hydrophilic amino acids such as serine and tyrosine, but not hydrophobic ones.

Figures 5 and 6 show ${ }^{1} \mathrm{H}$ NMR spectra for mixtures of COS and lysine-serine $(3: 1)$ copolymer with $\bar{M}_{w}$ of $32 \times 10^{3}$ and lysine-tyrosine copolymer $(4: 1)$ with $\bar{M}_{w}$ of $25 \times 10^{3}$ in different molar ratios of COS to the copolylysine, respectively. In these mixtures, the highest contents of gellike complexes were obtained in $79 \%$ and $63 \%$ for the molar ratio based on 4 and 5 amino acid residues of 3.2 and 4.2 , respectively. These molar ratios corresponded to the anions-to-cation ratio of about 1.0 in both mixtures.

On the other hand, precipitates were produced by interactions of $\mathrm{COS}$ with copolysines containing hydrophobic amino acids such as lysine-alanine $(1: 1)$, lysine-alanine $(3: 1)$, lysine-phenylalanine $(1: 1)$, and lysine-tryptophan $(4: 1)$ copolymers. The maximum amount of powdery precipitates was also obtained in the ionic ratio of 1.0 . This phenomenon suggests that appropriate solubility or swellability to water was necessary for the formation of gellike complexes and that the copolylysines containing such hydrophobic amino acids had not sufficient hydrophilicity to be used as biological model proteins.

\section{Factors Controlling Formation of the Gellike Polyion Complex \\ Effects of $p H$. Effects of $\mathrm{pH}$ on formation of the gellike} complex were examined for a mixture consisting of COS with $\bar{M}_{w}$ of $60 \times 10^{3}$ and $\mathrm{PL} \cdot \mathrm{HBr}$ with $\bar{M}_{w}$ of $7.5 \times 10^{3}$ in the molar ratio of 1.0. This result is depicted in Figure 7. By formation of the gellike complex, the $\varepsilon$ proton of polylysine side chain was split into two peaks in the $\mathrm{pH}$ range of 2.3 to 9.3 . On the other hand, no absorptions due to the complex appeared at a strong basic $\mathrm{pH}$ of

Table II. Chemical shifts of polylysine side chains of polylysine $\cdot \mathrm{HBr}$ and gellike complexes

\begin{tabular}{|c|c|c|c|c|c|c|c|c|c|c|c|}
\hline \multirow{3}{*}{$\begin{array}{l}\text { Gellike } \\
\text { polyion } \\
\text { complex }\end{array}$} & \multirow{3}{*}{$\mathrm{ds}^{\mathrm{a}} / \mathrm{dc}^{\mathrm{b}}$} & \multirow{3}{*}{$\begin{array}{l}\text { Molar } \\
\text { ratio }^{c}\end{array}$} & \multicolumn{9}{|c|}{ Chemical shift (ppm) ${ }^{d}$} \\
\hline & & & \multicolumn{2}{|c|}{$\mathrm{H} \alpha$} & \multicolumn{2}{|c|}{$\mathrm{H} \beta$ and $\mathrm{H} \delta$} & \multicolumn{2}{|c|}{$\mathrm{H} \gamma$} & \multicolumn{2}{|c|}{$\mathrm{H} \varepsilon$} & \multirow{2}{*}{$\mathrm{D}_{2} \mathrm{O}^{\circ}$} \\
\hline & & & $\alpha_{\mathrm{HBr}}{ }^{\mathrm{f}}$ & $\alpha_{\mathrm{g}}^{\mathrm{g}}$ & $\beta, \delta_{\mathrm{HBr}}$ & $\beta, \delta_{\mathrm{g}}$ & $\gamma_{\mathrm{HBr}}$ & $\gamma_{\mathrm{g}}$ & $\varepsilon_{\mathrm{HBr}}$ & $\varepsilon_{\mathrm{g}}$ & \\
\hline $\mathrm{PL} \cdot \mathrm{HBr}^{\mathrm{h}}$ & & & 4.33 & & 1.73 & & 1.48 & & 3.04 & & \\
\hline COS-PL $L^{i}$ & $0.5 / 0.5$ & 1.0 & & 4.18 & & 1.60 & & 1.35 & & 2.90 & 4.63 \\
\hline CS-PL ${ }^{j}$ & $1.5 / 0$ & 0.8 & & 4.12 & & 1.55 & & 1.29 & & 2.86 & 4.55 \\
\hline Hep-PL ${ }^{k}$ & $1.5 / 0.5$ & 0.6 & & 4.08 & & 1.50 & & 1.25 & & 2.81 & 4.51 \\
\hline
\end{tabular}

${ }^{a}$ ds means degree of sulfation in saccharide unit. ${ }^{b} \mathrm{dc}$ means degree of carboxylation in saccharide unit. ${ }^{\mathrm{c}}$ Molar ratio of sulfated polysaccharide to polylysine in formation of maximum amount of the gellike complex. ${ }^{\mathrm{d}}$ Recorded in $\mathrm{D}_{2} \mathrm{O}$, using DSS as a standard $(0.015 \mathrm{ppm}) .{ }^{\mathrm{e}}$ Entrapped $\mathrm{D}_{2} \mathrm{O}$ in the gellike polyion complex. ${ }^{\mathrm{f}}$ Absorptions due to polylysine hydrobromide. ${ }^{\mathrm{g}}$ Absorptions due to polylysine side chains of the gellike complex. ${ }^{\text {h }}$ Polylysine hydrobromide (PL) having $\bar{M}_{w}$ of $7.5 \times 10^{3}$. ${ }^{\text {i }}$ Formed in mixture of chondroitin-6-sulfate having $\bar{M}_{w}$ of $60 \times 10^{3}$ with PL having $\bar{M}_{w}$ of $7.5 \times 10^{3}$. ${ }^{\mathrm{j}}$ Formed in mixture of curdlan sulfate having $\bar{M}_{w}$ of $79 \times 10^{3}$ with PL having $\bar{M}_{w}$ of $7.5 \times 10^{3}$. ${ }^{\mathrm{k}}$ Formed in mixture of heparin having $\bar{M}_{w}$ of $3 \times 10^{3}$ with PL having $\bar{M}_{w}$ of $8 \times 10^{3}$. 


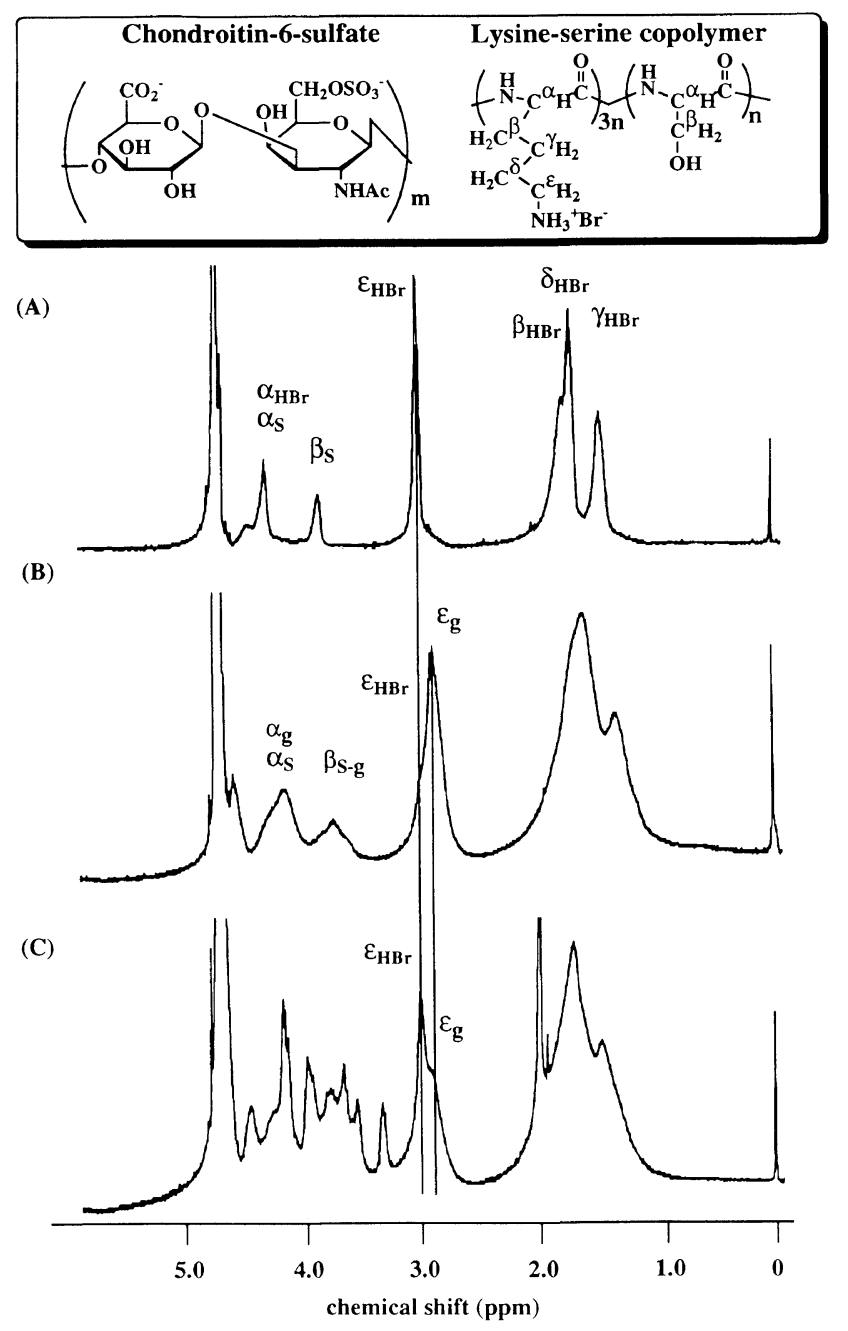

Figure 5. $400 \mathrm{MHz}{ }^{1} \mathrm{H}$ NMR Spectra of polyion complexes between COS and lysine-serine $(3: 1)$ copolymer (LSC) in different molar ratios [COS/LSC]. (A): LSC and mixtures in the molar ratio of (B): 3.2, and (C): 4.8 .

12.5 , indicating that the ionic interaction was completely suppressed in high basic $\mathrm{pH}$ regions possibly due to deprotonation of ammonium group of polylysine.

Figure 8 shows dependence of the proportion of the gellike complex on $\mathrm{pH}$. The proportion of the gellike complex changed considerably with ionic states of $\mathrm{COS}$ and $\mathrm{PL} \cdot \mathrm{HBr}$. In $\mathrm{pH}$ range of 3.9 to 7.8 , the proportion of the gellike complex ranged from $76 \%$ to $81 \%$. When $\mathrm{pH}$ was decreased to 2.3 , the proportion of the gel remarkably reduced to $24 \%$, probably due to partial dissociation of carboxyl groups in COS, as was the case of heparin and $\mathrm{PL} \cdot \mathrm{HBr}$ mixture. ${ }^{15}$ So far, ionic interactions of carboxyl anions with basic amino acids have been demonstrated in the binding of nonsulfated heparin trisaccharide with fibroblast growth factor.$^{18} \mathrm{On}$ the other hand, as $\mathrm{pH}$ increased, the proportion of gellike material decreased to $42 \%$ at $\mathrm{pH} 9.3$ and disappeared completely at $\mathrm{pH} 12.5$. The decrease in the proportion can be ascribed to a decrease in the $\mathrm{NH}_{3}^{+}$groups in polylysine at high $\mathrm{pHs}$.

Effects of the Molecular Weight of Polylysine. In Figure 9, the proportion of the gellike complex was plotted against molecular weight of lysine derivatives. Gellike complexes were obtained in the proportion from

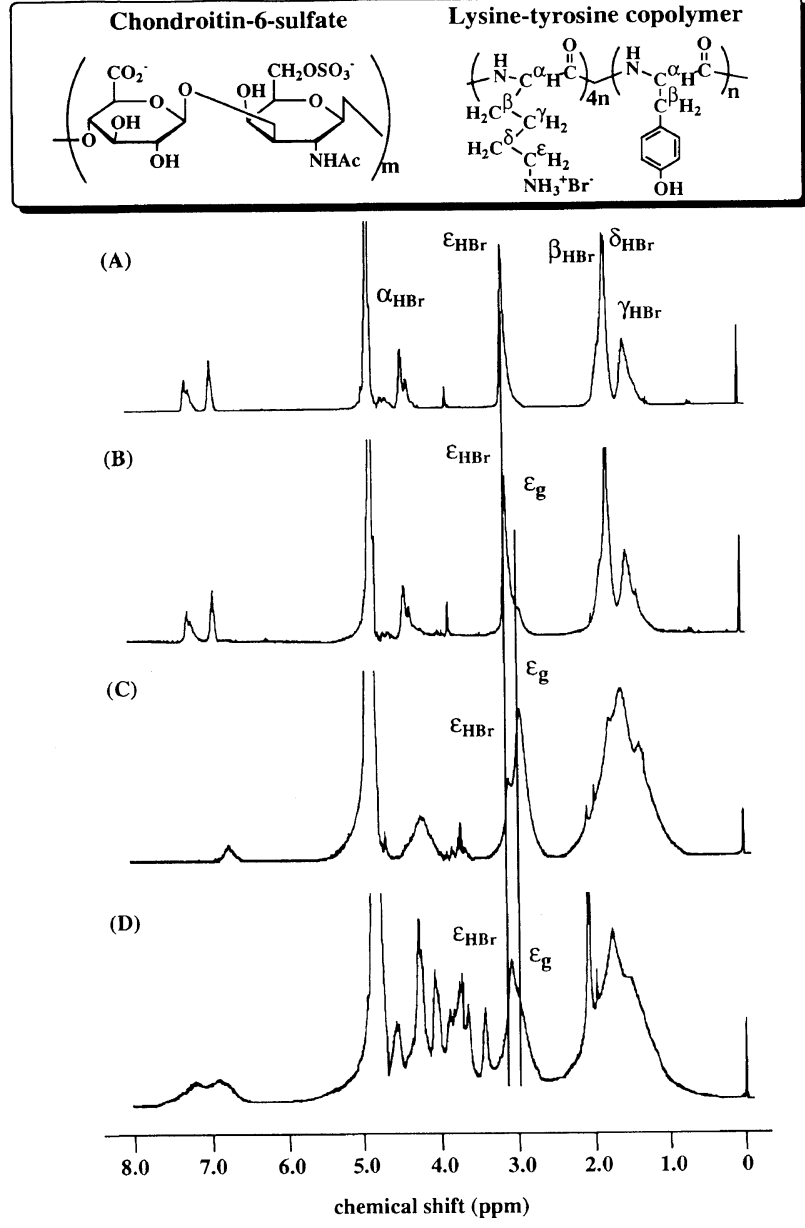

Figure 6. $400 \mathrm{MHz}{ }^{1} \mathrm{H}$ NMR Spectra of polyion complexes between COS and lysine-tyrosine $(4: 1)$ copolymer (LTC) in different molar ratios $[\mathrm{COS} / \mathrm{LTC}]$. (A): LTC and mixtures in the molar ratio of (B): $2.1,(\mathrm{C}): 4.2$, and (D): 6.4 .

$61 \%$ to $92 \%$ by interactions of COS with lysine derivatives from tetramer to polylysine with $\bar{M}_{w}$ of $56 \times 10^{3}$. In spite of low molecular weights, lysine tetramer and lysine pentamer formed the gellike complexes equivalent to polylysine. With COS having lower solubility in water, the degree of polymerization of 4 was enough for the polypeptide to form the cross-linked gel. For polylysines with the molecular weight larger than $10 \times 10^{3}$, the proportion of gels exhibited a tendency to decrease with increasing molecular weight. Instead, a large amount of precipitates was produced by use of polylysine with the molecular weight more than $56 \times 10^{3}$.

In the case of high molecular weight PLs, the decrease in the proportion of gellike material was replaced by an increase in the amount of powdery precipitates. Since the precipitates must be high-molecular-weight hydrophobic materials, they lost their solubility in water.

Effects of Concentration. Dependence of the proportion of the gellike complex on molar ratio was examined by use of polylysine $\cdot \mathrm{HBr}$ with $\bar{M}_{w}$ of $7.5 \times 10^{3}$ in the $\mathrm{PL} \cdot \mathrm{HBr}$ concentration of 1.0 and $2.8 \%$. As shown in Figure 10, the proportion of the gel remarkably varied with the molar ratio and the concentration of polyions. For a molar ratio of 1.0, the maximum amounts of gellike complex were $81 \%$ and $91 \%$ in the $\mathrm{PL} \cdot \mathrm{HBr}$ at concentration of $1 \%$ and $2.8 \%$, respectively. In par- 


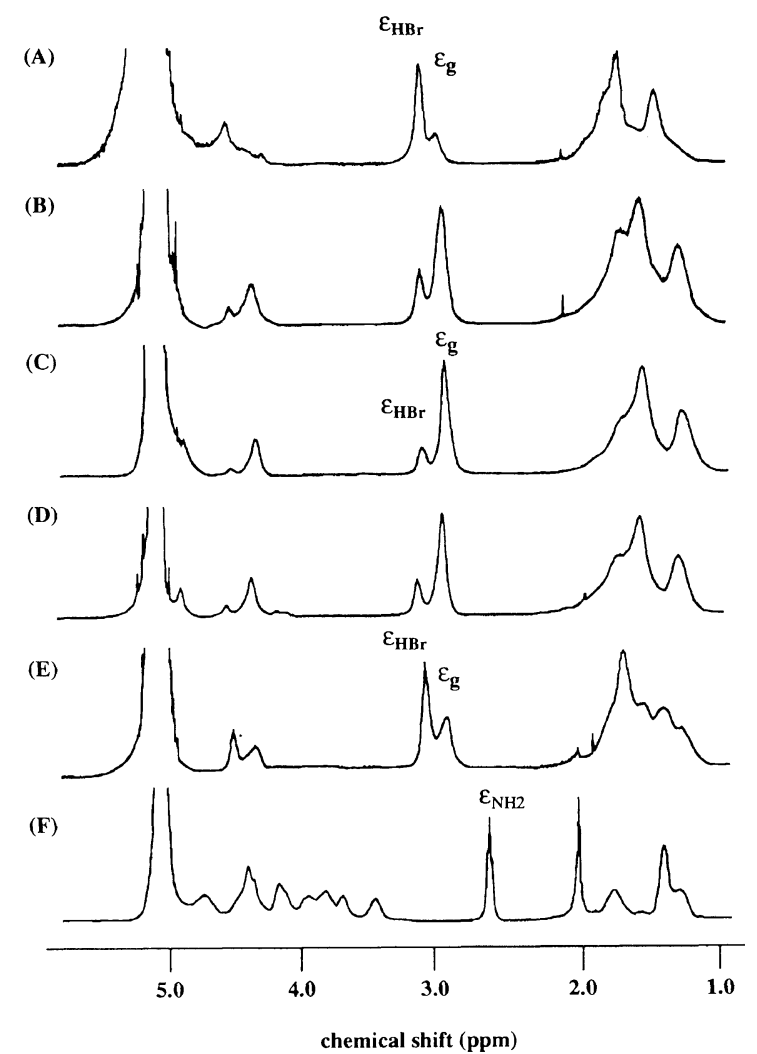

Figure 7. $400 \mathrm{MHz}{ }^{1} \mathrm{H}$ NMR Spectra of polyion complexes between $\mathrm{COS}$ and $\mathrm{PL} \cdot \mathrm{HBr}$ in different $\mathrm{pHs}$ in the molar ratio of 1.0 . (A) $\mathrm{pH}$ 2.3, (B) 3.9, (C) 6.4, (D) 7.8, (E) 9.3, and (F) 12.5. The concentration of PL is $1.0 \%(\mathrm{w} / \mathrm{v})$.

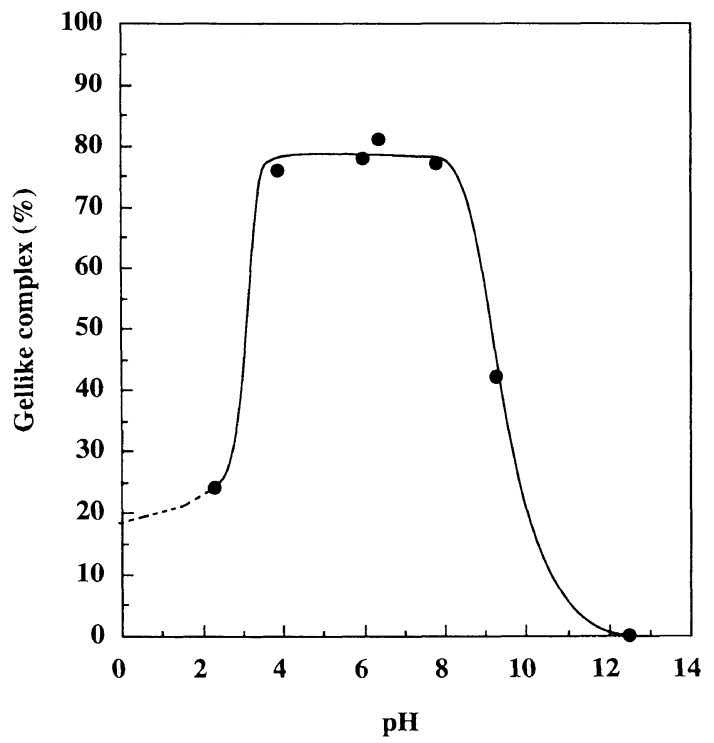

Figure 8. Dependence of the proportion of the gellike complex on $\mathrm{pH}$ in a mixture of $\mathrm{COS}$ and $\mathrm{PL} \cdot \mathrm{HBr}$ in the molar ratio of 1.0. The concentration of PL is $1.0 \%(\mathrm{w} / \mathrm{v})$. No precipitates were observed.

ticular, the molar ratio above 1.0 , the proportion of gel depended to a large extent on the concentration. In the case of low concentrations, turbid solutions were obtained, probably due to incomplete cross-linking in which polyion complexes had not enough molecular weight to form the gellike complex.

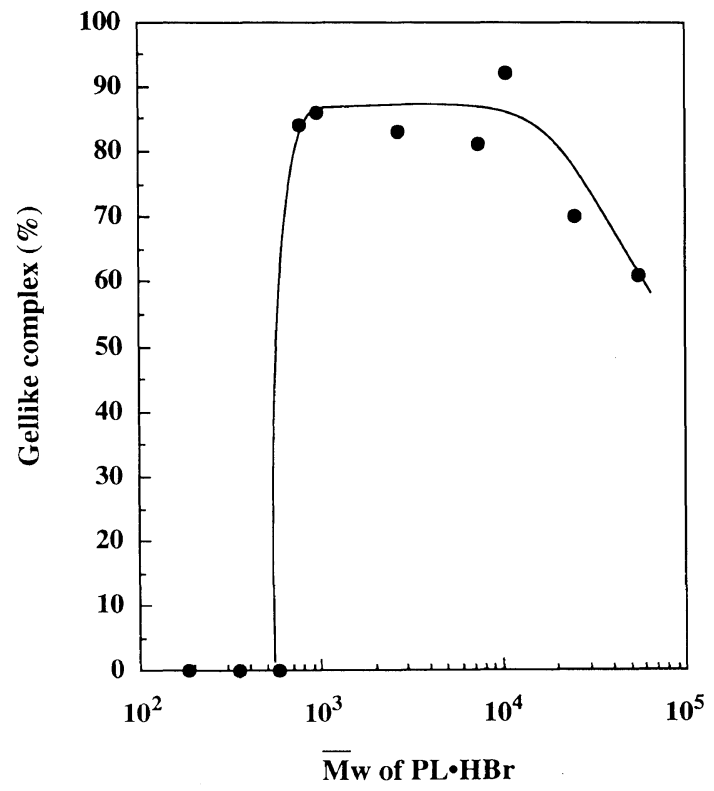

Figure 9. Dependence of the proportion of the gellike complex on molecular weight of PL in molar ratio of 1.0. The concentration of PL is $1.0 \%(\mathrm{w} / \mathrm{v})$.

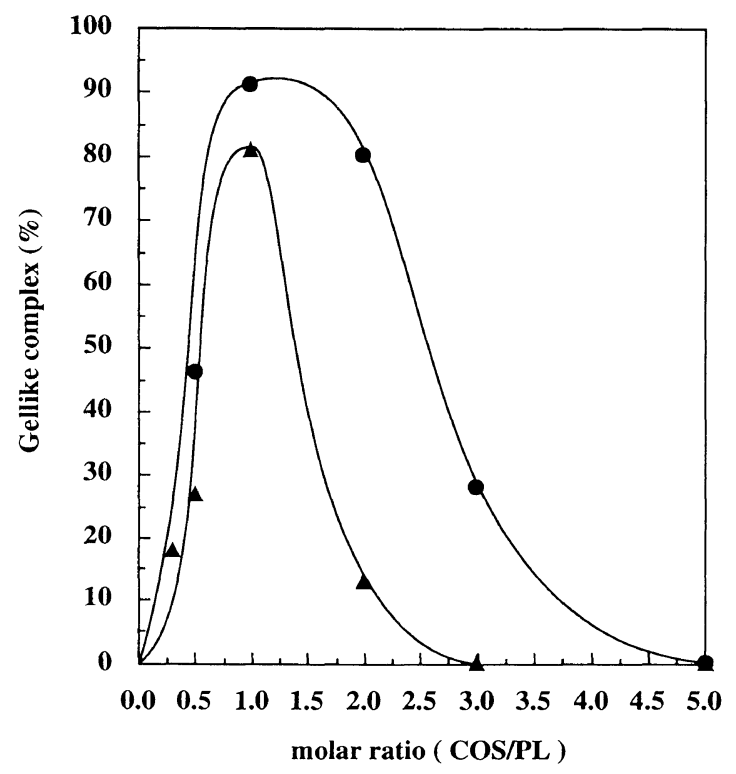

Figure 10. Dependence of the proportion of the gellike complex on concentration and molar ratio. Concentration of $\mathrm{PL} \cdot \mathrm{HBr}$ in $\mathbf{A}: 1.0 \%$ $(\mathrm{w} / \mathrm{v})$ and $-2.8 \%(\mathrm{w} / \mathrm{v})$. No precipitates were observed.

\section{REFERENCES}

1. G. Sundblad, S. Kajiji, V. Quaranta, H. H. Freeze, and A. Varki, J. Biol. Chem., 263, 8897 (1988).

2. A. D. Snow, D. Nochlin, R. Sekiguchi, and S. S. Carlson, Exp. Neurol., 138, 305 (1996).

3. E. Ruoslahti, Ann. Rev. Cell Biol., 4, 229 (1988).

4. R. L. Jackson, S. J. Busch, and A. D. Cardin, Physiol. Rev., 71, 481 (1991).

5. T. Toida, H. Toyoda, and T. Imanari, Anal. Sci., 9, 53 (1993).

6. J. T. Gallagher, Curr. Opin. Cell Biol., 1, 1201 (1989).

7. R. J. Mckeon, R. C. Schreiber, J. S. Rudge, and J. Silver, J. Neurosci., 11, 3398 (1991).

8. A. Oohira, R. Katoh-Semba, E. Watanabe, and F. Matsui, Neurosci. Res., 20, 195 (1994).

9. J. Shioi, J. P. Anderson, J. A. Ripellino, and N. K. Robakis, $J$. Biol. Chem., 267, 13819 (1992).

10. D. A. De Witt, J. Silver, D. R. Canning, and G. Perry, Exp. 
Neurol., 121, 149 (1993).

11. A. Garcia-Pardo, A. Rostagno, and B. Frangione, Biochem. J., 241, 923 (1987)

12. A. Baird, D. Schubert, N. Ling, and R. Guillemin, Proc. Natl. Acad. Sci. U.S.A., 85, 2324 (1988).

13. M. Presta, J. A. M. Maier, and G. Ragnotti, J. Cell Biol., 109, 1877 (1989).

14. K.-J. Jeon, K. Katsuraya, Y. Kaneko, T. Mimura, and T. Uryu, Macromolecules, 30, 1997 (1997).
15. K.-J. Jeon, K. Katsuraya, Y. Kaneko, T. Mimura, and T. Uryu, Sen'i Gakkaishi, 53, 301 (1997).

16. G. J. Cole, D. Schubert, and L. Glaser, J. Cell Biol., 100, 1192 (1985).

17. A. A. Reyes, R. Akeson, L. Brezina, and G. J. Cole, Cell Regul., 1, 567 (1990).

18. D. M. Ornitz, A. B. Herr, M. Nilsson, J. Westman, C.-M. Svahn, and G. Waksman, Science, 268, 432 (1995). 